\title{
Economics of Cinnamomum glaucescens (Nees.) Drury in Western Terai Region of Nepal: A Value Chain Perspective
}

\author{
Prabina Sharma ${ }^{1}$ and Keshav Raj Acharya ${ }^{{ }^{*}}$
}

\begin{abstract}
This study was carried out in Chillikot village of Dang district to find out the economic contribution of Cinnamomum glaucescens to local economy and to document the major conservation threats for this species. Household survey $(n=29)$, key informants interviews $(n=5)$ and focus group discussions $(n=3)$ were carried out to collect the data. This study reveals that about NPR 1.7 million (US $\$ 16,500^{2}$ ) have been contributed annually to local economy by 29 households from NTFPs including C. glaucescens berries collection business. Average annual income for each household was around US\$ 569.19 from the species that contributes about $53 \%$ of the total annual household income. Value chain analysis showed that six different value chain actors were found involved in C. glaucescens business with maximum profit margin to wholesaler (US\$ $1.66 \mathrm{~kg}^{-1}$ ) and minimum to village traders ( US\$ $0.07 \mathrm{~kg}^{-1}$ ). Open access to the resource and poor functional linkage among the actors were identified as major limitations in the value chain of the products. Handing over the national forest as a community forest, linking the producers with processor through organized market channel has been recommended for future.
\end{abstract}

Key words: Community forest, C. glaucescens, economic contribution, NTFP, value chain

Sharma, P. and K. R. Acharya. 2020. Economics of Cinnamomum glaucescens (Nees.) Drury in Western Terai Region of Nepal: A Value Chain Perspective. No. 17: page 102 to 117. DOI: https://doi.org/10.3126/forestry.v17i0.33625

1 Tribhuvan University, Institute of Forestry, Pokhara

Corresponding author, email: kracharya@iofhc.edu.np

2 Exchange Rate US\$ 1= NPR 118 


\section{Introduction}

Nepal is rich in biodiversity harbouring about 7000 plant species out of which about $10 \%$ have medicinal value. About 100 species have been commercially traded from Nepal (Edwards 1996; GIZ 2011). Total traded value of medicinal herbs and essential oil was 1.3 million US\$ in fiscal year 2017/18 (TEPC 2018). Two regions (MidWestern and Far-Western) together contribute more than $85 \%$ of the total collection of medicinal herbs in Nepal (GIZ 2011). Cinamomum glaucescens (Nees.) Drury, also known synonymously as Cinamomum Cecidodaphne Meissn and locally called Sugandhakokila, is native to the tropical Himalayan regions of Nepal and India. It could be found naturally in hills and plains up to an altitude of $1200 \mathrm{~m}$ (Rani et al. 2017). It has also been reported in Bhutan (Jakson 1994). C. glaucescens is one of 39 important oil producing species of Nepal for extraction of essential oil from its berries (Gurung 2010); however, the species is banned for export to other countries without processing (GoN 1995). This large-sized evergreen tree belongs to Lauraceae family and grows in the wild in Dang, Rolpa and Salyan districts of mid-western Nepal (Rema et al. 2002; Adhikari 2018). C. glaucescens is one of the highly commercial aromatic plants for extraction of essential oil so it is identified as prioritized medicinal and aromatic plants (MAPs) for economic development in Nepal (DPR 2012).

Division forest office (DFO) Dang has identified C. glaucescens as a priority species for value chain development together with Zanthoxylum armatum, Cinnamomum tamala, Diploknemabutyracea and Mentha arvensis among the hundred different medicinal and aromatic plants species (MAPS) traded from the district (DFO 2017). C. glaucescens has been reported in 627 ha forest area in the stock of $67.98 \mathrm{~kg} \mathrm{ha}^{-1}$ dry berries per year among the potential of 1792 ha in the district (DFO 2018). This information reveals that annual stock of dry berries in the district was 42.62 metric ton (MT). Division forest office has a provision to allow the harvest of $80 \%$ of fruits. Thus, 34.10 metric ton dry berries could be harvested in sustainable way from the districts annually (DFO 2018).

Value chain approach emphasises a range of activities and market linkages to help entrepreneurs including growers to enhance the quality of products and fetch a higher price, thus increasing household income (Shah et al. 2018). Value chain activities can be used to add value on every step of the chain by systematically improving the quality of the products through grading, packaging and connecting the farmers with markets (Mohan 2016). Considering the great natural stock and the demands for proper management of the species to optimize its economic contribution, this study was conducted to document the economics of this valuable species in the local context as well as to explore the relationship among the actors who are involved in the value chain. 


\section{Methods and Meterials}

\section{Study Area}

The study was conducted in Dang district. The district covers an area of 2,955 sq.km within $82^{\circ} 2^{\prime}$ to $82^{\circ} 54^{\prime}$ E longitudes and $27^{\circ} 36^{\prime}$ to $28^{\circ} 29^{\prime} \mathrm{N}$ latitudes with an altitude ranging from 213 to $2058 \mathrm{~m}$. Maximum temperature ranges from $20.5^{\circ} \mathrm{C}$ to $39.9^{\circ} \mathrm{C}$ and minimum temperature ranges from $21.8^{\circ} \mathrm{C}-2.5^{\circ} \mathrm{C}$. On an average Dang receives 1,706mm of rainfall annually (DDC 2071). Dang consists of two tropical valleys: Dang and Deukhuri. Cinnamomum glaucescensis only found in Dang valley that lies between the Mahabharat Range in the north and the Churia Range in the south (DFO 2017).
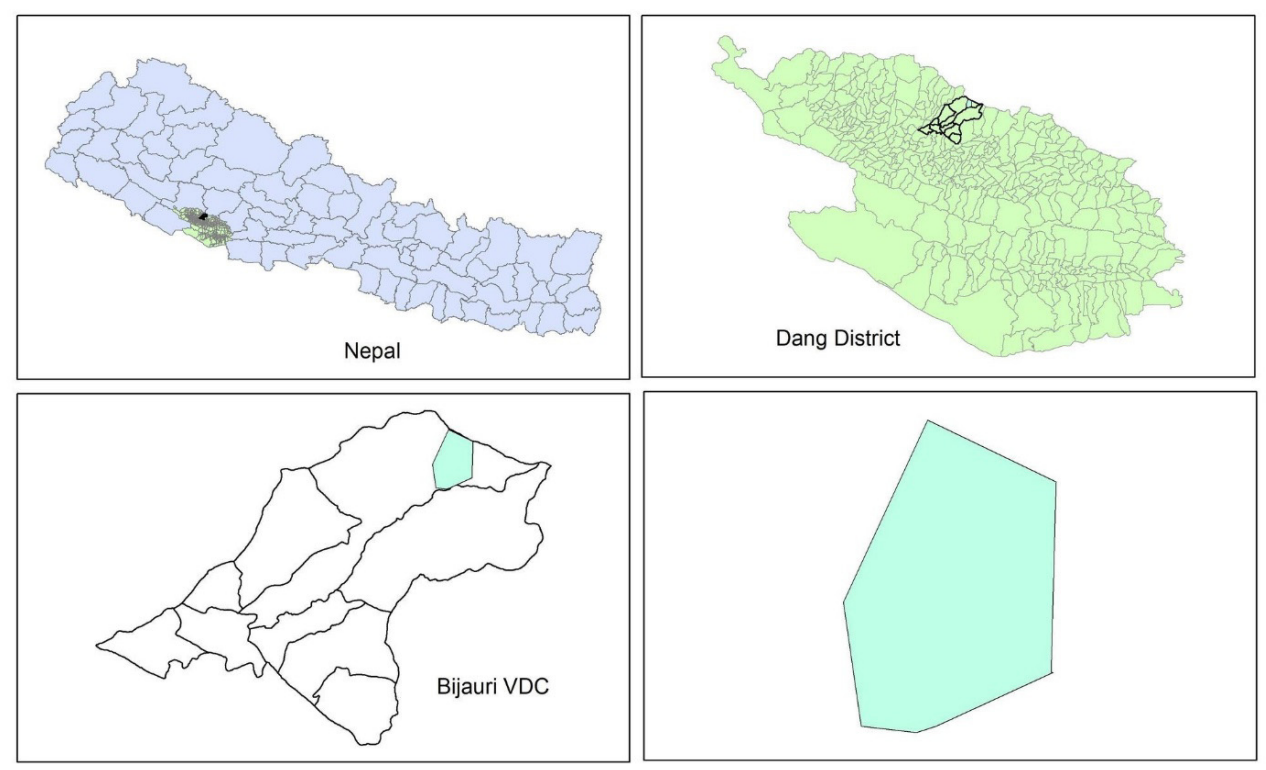

Figure 1: Location map of study area

Cinnamumumglaucescens has been recorded in four different municipalities, namely Baglachuli, Ghorahi, Tulsipur and Shantinagar; however, it is densely populated in the forest arround Chillikot village in Tulsipur sub-metropolitan area. This village is located in northernmost part in hilly terrain from the altitude of $1000 \mathrm{~m}$ to $1475 \mathrm{~m}$ and connected to Rolpa district in northern side (DDC 2013). It was under the Bijauri village development committe (VDC) before state restructure in Nepal; however, it came under Tulsipur sub-metropolitan city after the new federal restructure (DCC 2018). Total of 183.60 ha forest area is covered by the dominance of C.glaucescens associated with Shorea robusta, Pinus roxburghii, Zanthoxylum armatum, Diploknima butyraceae and Thysanilaena latifolia. The village is sparsely populated with 29 
households whose main occupation is agriculture, but they are also involved in nonTimber Forest Product (NTFP) collection. Some of the villagers are in foreign imployment (VDC 2010). Most of the households have been engaged in the collection of $C$. glaucescens for sustaining their livelihood.

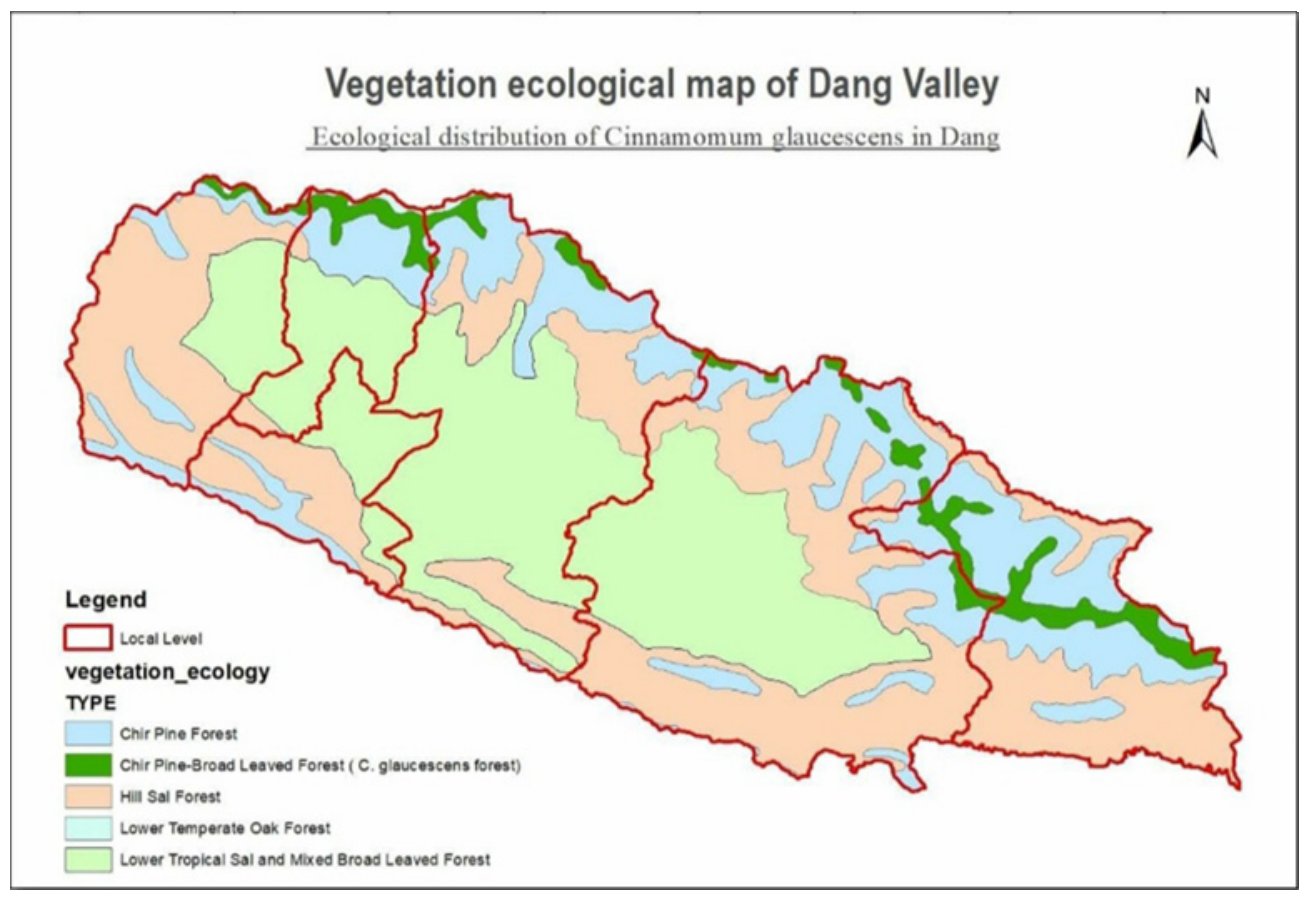

Figure 2: Vegetation map of $C$. glaucescensin Dang Valley (dark green color) (Source: DFO)

\section{Data Collection}

Both primary and secondary data were collected for the study. Questionaire survey was the main method applied for acquiring the information. Questionaire survey was carried out with all households $(n=29)$ in the area who were usually involved in C. glaucescens berries collection. For household survey, household head was consulted for the information. In the absense of household head, the persons involved in the household decisions were consulted. A questionnaire consisting of the questions related to collection of $C$. glaucescens berries, marketing channel and price trends for last three years were used. Similarly, income from C. glaucescens was also included in the questionnaire. Among the total respondents, more than two third $(69 \%)$ were males and nearly half of the respondents $(52 \%)$ belong to Magar ethnic group followed by $38 \%$ of Chhetri. The education level of the village was poor, so nearly half of the respondents were just literate without any formal education and only $12 \%$ respondents had secondary level education. The income source of the majority of respondents was non-timber forest product (NTFP) 
collection (53\% share of household income) followed by agriculture $(20 \%)$ and remittances $(19 \%)$.

Focus group discussion $(n=3)$ was another method applied for the data collection. Women group, poor individuals and local traders were involved in seperate focus group discussions. Each group had 5-10 individuals but all groups had seperate representations. Each focus group discussion was about one hour that was basically confined to business trends and threats to concerrned each group regarding the business.

Key informant survey $(n=5)$ was conducted to verify the information collected from household survey and focus group discussions. DFO, municipality representatives and regional traders were the key informants for the study. Key informants were consulted for authentic data about the resource base and the traded amount on annual basis. With the help of information collected through all methods, a detailed value chain map was developed. Information from division forest office (DFO) and published as well as unpublished reports were also used as secondary information. Received information was analysed by using simple statistical tools like mean, frequency and percentage. Analysed data were presented in chart, table and figure.

\section{Results and Discussion}

\section{Results}

The findings of this research have been categorized into five dimensions namely economic scope, value chain analysis, harvesting, packing and storage, conservation status and SWOT (strength, weakness, opportunity and Threats) analysis.

\section{Economic Scope}

The information received from district forest office reveals that in the year 2016/17 (Nepalese fiscal year 2073/74), total of 95.325 metric ton (MT) dry berry of $C$. glaucescens was exported from the district. For fiscal year 2074/75, 2075/76 and 2076/77 the exported amounts were 33.450 MT, 33.150 MT and 34 MT respectively. More than one third of the amount $(34.80 \%)$ exported from the district was contributed by the study area only. Total of 11.642 MT dry berries were collected from study site in fiscal year 2074/75. The average collection per household was found $400 \mathrm{~kg}$ dry berries with minimum of $100 \mathrm{~kg}$ to maximum of $800 \mathrm{~kg}$. Among the total households, $21 \%$ households sold 100 to $200 \mathrm{~kg}$ dry berries and $14 \%$ sold about $800 \mathrm{~kg}$ dry berries (Figure 3). The average price of dry berries in local market was NPR 150, highly fluctuating from NPR 120 to 160 for each kilogram $(\mathrm{kg})$. 


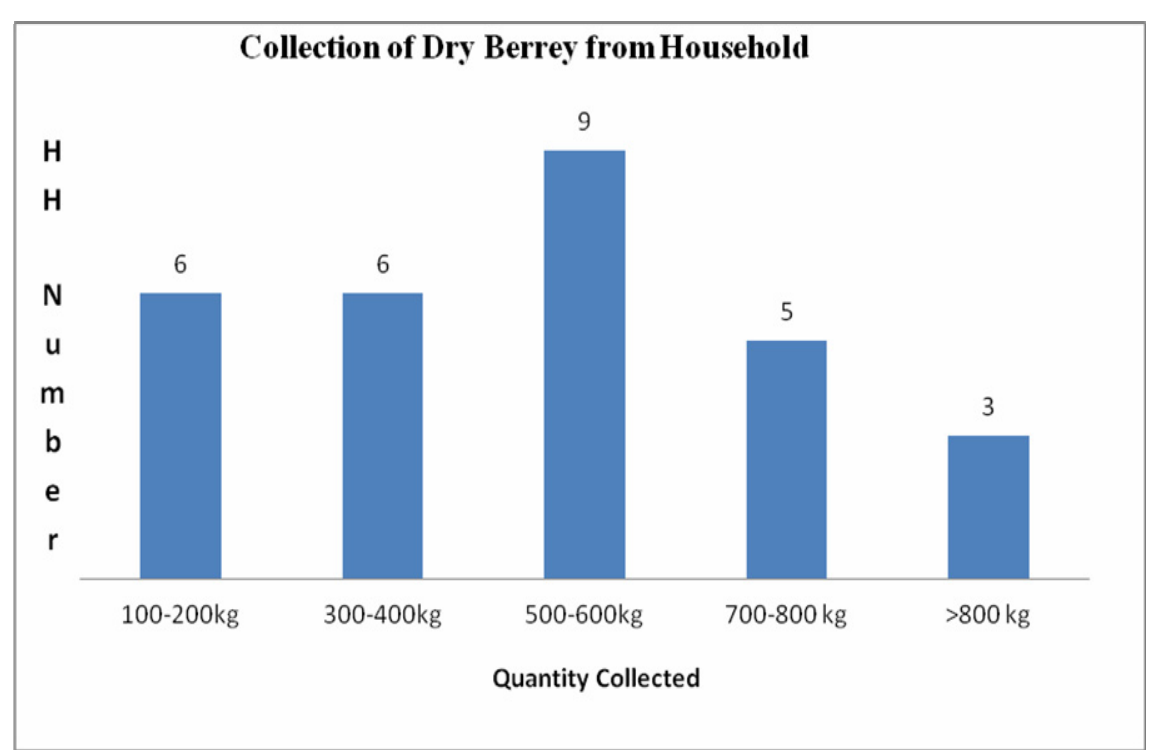

Figure 3: $C$. glaucescens collection by households in the study site

This study reveals that average annual income in each household from the sale of $C$. glaucescens was NPR 67,265.38 (US\$ 569.19 at exchange rate $1 \$=118$ NPR), that is, about $53 \%$ of the total average household annual income of that area. The maximum income was NPR 200,000 and minimum was NPR 28,000 per household annually. Total of NPR 17, 46,300 was received in the area from the sale of $C$. glaucescens berries alone. Majority of the respondents were found dependent on the local traders for the price of the products and local people were compelled to early harvest to make some income in September to celebrate Dashain \& Tihar.

The price during festival periods (such as Dashain and Tihar) was found lower than in normal period. However, the price provided by the local traders was found to have gradually increased from the year 2014. In 2014, the price was only NPR $6 \mathrm{~kg}^{-1}$, while in 2015 it was NPR $7 \mathrm{~kg}^{-1}$. Similarly, it was NPR $10 \mathrm{~kg}^{-1}$ in the year 2016 and NPR $12 \mathrm{~kg}^{-1}$ in 2017. During the study period (February-March, 2018) the price was NPR $16 \mathrm{~kg}^{-1}$. Figure 3 shows the trend of market price for dry C. glaucescens berries in the village. Generally, the berries were sold in quintal bag, so the price at the village level in quintal is shown in the Figure 4.

\section{Role of Value Chain Actor's and Supporter's}

An attempt was made to identify the major stakeholders for C. glaucescens value chain. District Coordination Committee (DCC), municipalities, division forest office, district chapter of Jadibuti Association of Nepal (JABAN), Nepal Herbs and Herbal Products Associations (NEHHPA), Federation of Community Forest Users Nepal (FECOFUN) and District Chamber of Commerce and Industries (DCCI) were identified as major stakeholders at district level and Ministry of Forest and Soil conservation, Department of Forest, Department of Plant Resources, Trade 
Promotion Center and Ministry of commerce and supplies, JABAN, NEHHPA and FECOFUN as well as Federation of Nepalese Champers of Commerce and Industry (FNCCI) at national level for overall medicinal and aromatic plants sub-sector. However, these organizations had little knowledge and interest in C. glaucescens value chain.

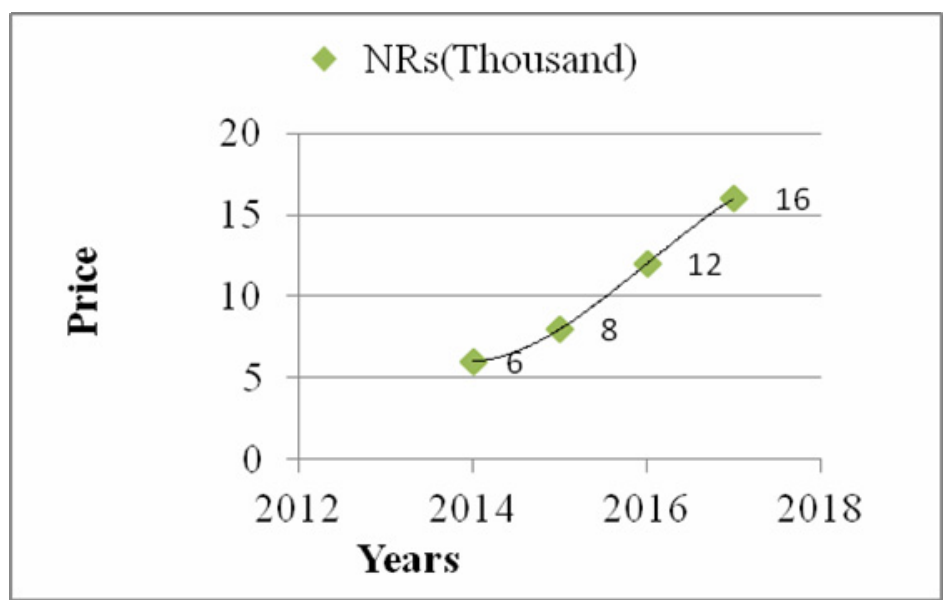

Figure 4: Trends of local market price since 2012 (for each quintal=100 Kg)

Government agencies like Tulsipur sub-metropolitan city and division forest office, Dang had to play a major role for stock maintenance but they were confined only to revenue collection from traders. The private sector organizations like chamber of commerce and industries (CCI), Jadibuti Association of Nepal (JABAN) and Nepal Herbs and Herbal Product's Association (NEHHPA) had to support in linking the producers and processors; however, no function was identified for value chain upgrading strategy. The role of Federation of Community Forest User's Nepal (FECOFUN) was also found very poor. The forest was not handed over as a community forest; so, it seemed like open access resource. In the absence of proper management and conservation plan, the resource was being exploited and losing its production potentiality as well.

No financial institutions were reported in the study site for value chain financing for NTFP products. Due to poor access to financial institutions, the product provided safety nets during emergencies and covered festival expenditure for local producers. Un-matured harvest and low price were observed before Dashain festival that excreted triple impact, i.e., inferior quality of the products, low price and poor regeneration.

A poor functional linkage was found among the actors and supporters of $C$. glaucescens value chain. Generally, regional traders take the export permit from forest authorities (DFO) and after paying the collection royalty they supply the products to primary processor. Not any linkage was found between the producers and processors. The price and quality could hike if the value chain supporters facilitated 
the actors to make connection between producers and processors. The processers could facilitate the producers to maintain the quality as well as provide fair price to the producers. The role of forest authority and local government was limited in the collection of revenue. Introduction of modern drying technology and facilitation on sustainable harvesting practices are the key areas identified for value chain interventions.

\section{Value Chain Analysis}

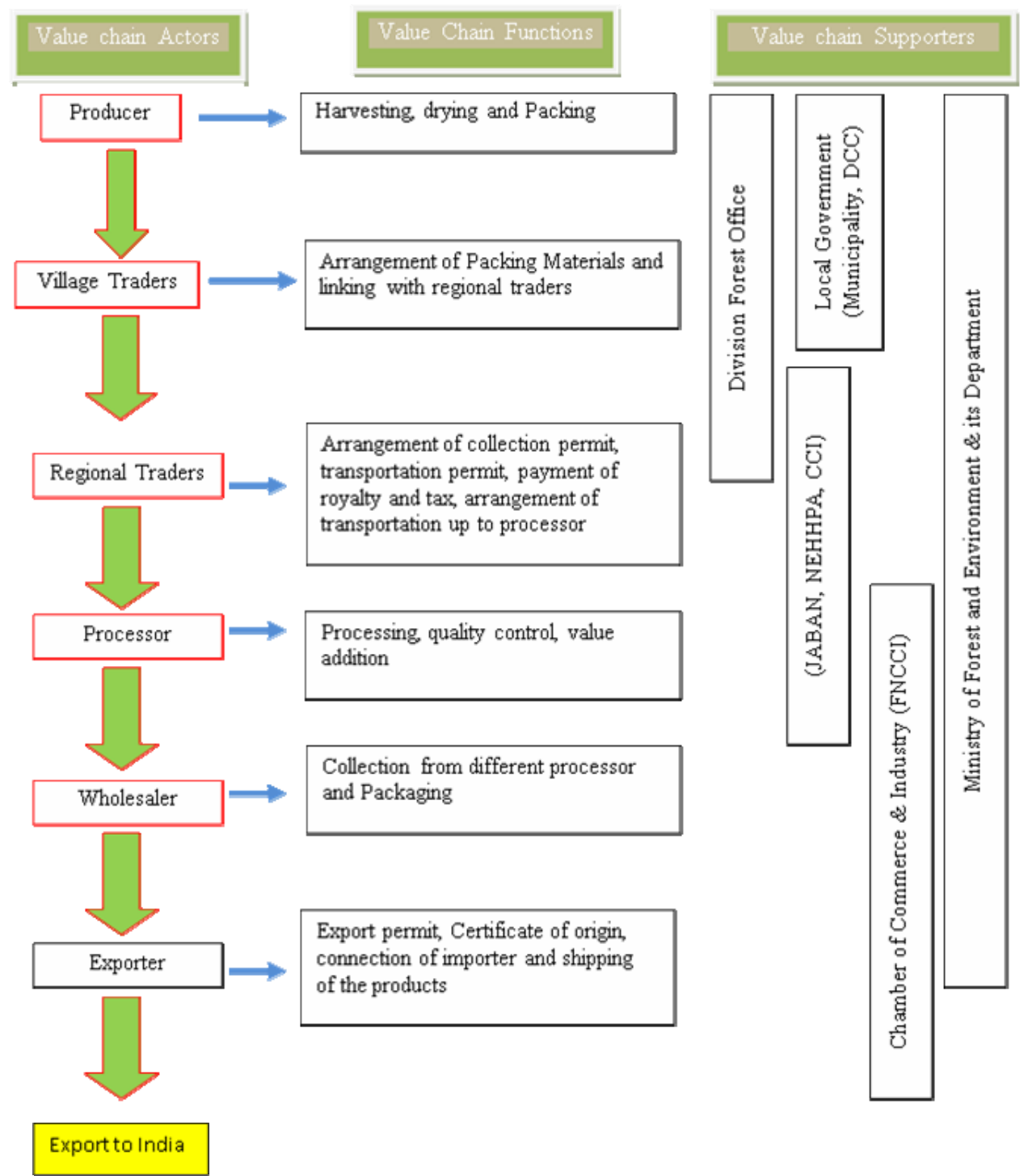

Figure 5: Major stakeholders and their functions in C. glaucescens value chain development 
Stakeholder map (Figure 5) and value chain map (Figure 6) show that different actors and supporters have been involved in the marketing of $C$. glaucescens to reach the products up to exporter as final productions have not been done inside the country. Two processed products namely essential oil and oil cake (residuals trade name Marca) could be obtained from C. glaucescens and both products are sold in the Indian market mostly via Nepalgunj. Altogether six different trade channels have been observed in the whole chain from producers up to exporter. Primary processor and exporters claim that the essential oil is used for perfumery and the cake (Marca) is used for high value incense making in India. In each trade channel, some value is added to the products with certain profit margin and added cost in each channels.

Table 1: Cost, profit margin and value addition in each trade channel (NPRkg- ${ }^{1}$ )

\begin{tabular}{|l|l|l|l|l|l|}
\hline Trade channels & Cost Price (C.P.) & Added cost & $\begin{array}{l}\text { Selling Price } \\
\text { (S.P.) }\end{array}$ & Profit Margin & $\begin{array}{l}\text { Value } \\
\text { addition }\end{array}$ \\
\hline Producer & & 11.14 & 150.00 & $138.86(25.9)$ & 138.86 \\
\hline Villager traders & 152.00 & 2.00 & 160.00 & $8.00(1.5)$ & 10.00 \\
\hline Regional Traders & 173.00 & 13.00 & 190.00 & $17.00(3.2)$ & 30.00 \\
\hline Primary Processor & 181.65 & 91.65 & 348.00 & $66.35(12.3)$ & 158.00 \\
\hline Wholesaler & 394.00 & 46.00 & 590.00 & $196.00(36.5)$ & 242.00 \\
\hline Exporter & 622.00 & 32.48 & 732.48 & $110.00(20.5)$ & $142 . .48$ \\
\hline Total & & 196.27 & & $536.21(100)$ & 721.34 \\
\hline
\end{tabular}

Note: Figures in parenthesis is the percentage of profit margin of all actor's

Maximum profit margin (36.5\%) was taken by the wholesaler (NPR $196 \mathrm{~kg}-1$ ) followed by producers (NPR $138.86 \mathrm{~kg}^{-1}$ ) and exporters (NPR $110.00 \mathrm{~kg}-1$ ). Though the market price for dried berries highly fluctuated from NPR $120 \mathrm{~kg}^{-1}$ to $160 \mathrm{~kg}^{-1}$, the opportunity cost for production (production cost) was estimated NPR $11.14 \mathrm{~kg}^{-1}$ by calculating labor cost at the local wage rate (NPR 500 day-1$^{1}$ person ${ }^{-1}$ ). The production cost included the cost of human labor for berry collection and efforts for drying and storage. Then the product was collected by village level traders due to inability of producer'sfor selling the products directly in market. Generally village level traders bore the cost for packing materials. The cost of packing materials (generally jute bag is used for packing which cost NPR 100 for having the capacity of $50 \mathrm{~kg}$ ) was only NPR $2.00 \mathrm{~kg}-1$.

Village level traders sold the product to regional traders. Regional traders generally took transit permit after paying the royalty to division forest office and local government. Regional traders sold dry berries to processors. The processing cost was found high for this species. The processing cost was calculated NPR $91.65 \mathrm{~kg}^{-1}$ as essential oil content is only eight percent in terms of dry weight of berry. After processing of $12.5 \mathrm{~kg}$ dry berry, $1 \mathrm{~kg}$ essential oil and $11 \mathrm{~kg}$ of residuals could be obtained. Market price for essential oil and marca during the study period was NPR $2700 \mathrm{~kg}^{-1}$ and NPR $150 \mathrm{~kg}-{ }^{-1}$ respectively. The processor gained the net profit of NPR $66.35 \mathrm{~kg}^{-1}$. Net income of village traders was NPR. $8.00 \mathrm{~kg}^{-1}$ and regional traders got 
the profit of NPR. $17.00 \mathrm{~kg}^{-1}$. During the final course of value chain, price of each kg dry berries was upgraded from NPR 11.14 to NPR. 732.48 (from production to export price) with NPR 196.27 added cost and NPR 536.21 total profit margin for all actors involved within the country.

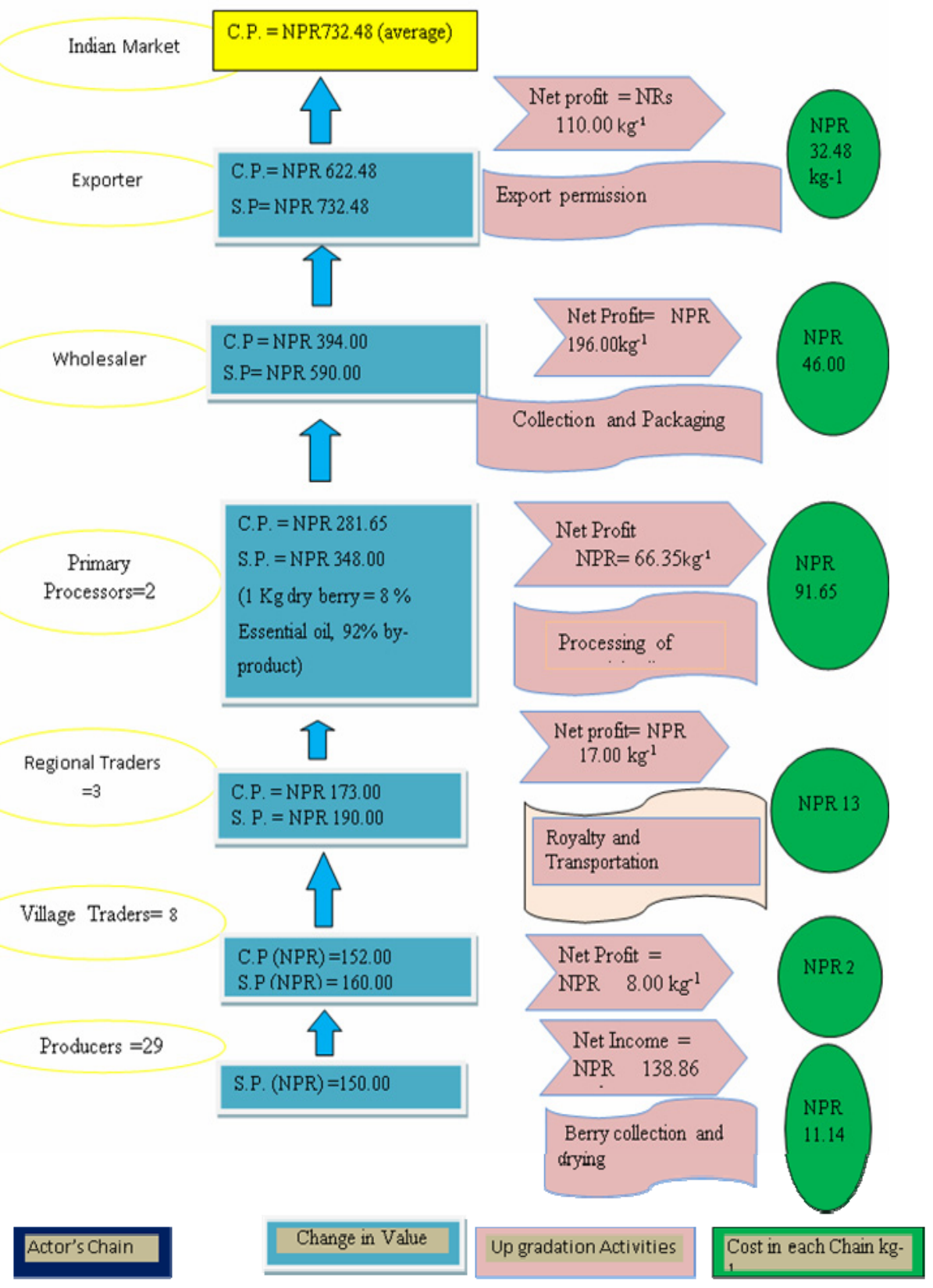

Figure 6: C. glaucescens Value Chain Map, 2018 


\section{Harvesting System}

C. glaucescens locally known as Malagiri. The C. glaucescens fruits are harvested between Bhadra and Kartik (August to November). As C. glaucescens trees grow big $\mathrm{DBH}$ and height, local people gather the fruits from the ground when someone climbs the trees and shakes the branches. Local people sometimes cut the branches to collect the berries but generally the collection is done from the ground after ripening and natural fall on the ground but large part of the fruits will be destroyed by monkey and birds. They do not have any modern equipment to climb and harvest the berries. After collection, the berries let to dry in shade under tree as sundry may deteriorate the quantity of essential oil from the pericarp. Once the berries dried, stored in jute bag and sold to village traders.

\section{Conservation Status}

C. glaucescens was abundantly found there and majority of the respondent (58\%) responded that the trees are constant in the study area however production has been found reduced due to presence of old tree. However, the regeneration was found poor in the forest. The trees were also found in both private lands as well. Though, the harvesting was done from the fallen seed so there were non-destructive harvesting practices; the regeneration was poor due to browsing by

\section{Harvesting, Drying and Packing Process}

The C. glaucescens fruits are harvested between Augusts to November (Bhadra to Kartik as per Nepali month) each year. As C. glaucescens trees grow with large diameter and height, local people gather fruits from the ground when someone climbs up the trees and shakes their branches. Local people sometimes cut the branches to collect the berries but generally collection is done from the ground. Locals do not have access to modern equipment to climb up the trees and harvest the berries. After collection, the berries are dried in shade under tree up to ten days as sundry deteriorates the quantity/quality of essential oil from the pericarp. Not any modern technology was introduced to dry the fruits. Once the berries are dried, they are stored in jute bag for the sale. Village traders pack the dried berries and make them ready for the sale to the regional traders.

\section{Conservation Status}

Though, there was a non-destructive harvesting practice, regeneration was poor due to browsing by goats in the area. The trees were also used for timber and fuel wood in the past; however, considering the increasing price of berries in recent years, this practice has been reduced. Majority of the respondents $(74 \%)$ claimed that insect attack was the major threat followed by browsing by goat $(20 \%)$ as goat rearing is another important livelihood options in the study area. The trees were also being used for timber and fuel wood in the past; however, because of the price of $C$. glaucescens berries has been increasing in recent years, this practice has been reduced. Due to low level of knowledge of the quality of products and limited availability of 
modern harvesting technology and damage by goat, monkey and birds were also causing threat for getting fair price as well as depleting the regeneration.

\section{SWOT Analysis}

SWOT analysis was also conducted during the study. Following are the major outcomes from the SWOT analysis in local context.

Table 2: SWOT Analysis C. glaucescens Value Chain

\begin{tabular}{|c|c|}
\hline $\begin{array}{l}\text { Strength } \\
\text { Suitable climatic, ecological and } \\
\text { physiographic condition } \\
\text { Increasing awareness among the locals } \\
\text { increasing trends of private plantation }\end{array}$ & $\begin{array}{l}\text { Weakness } \\
\text { Low level of education of the people } \\
\text { Not any technical training. } \\
\text { Locals not familiar with scientific management } \\
\text { Banned for export without processing } \\
\text { Lack of access to finance } \\
\text { No fresh cash with farmers to invest }\end{array}$ \\
\hline $\begin{array}{l}\text { Opportunity } \\
\text { Tool to reduce the poverty } \\
\text { Increasing trend of demand and price } \\
\text { Increased processing and value addition } \\
\text { Opportunity to contribute a lot to local as } \\
\text { well as sub-national economy }\end{array}$ & $\begin{array}{l}\text { Threats } \\
\text { No proper market; Monopoly of traders } \\
\text { High price fluctuation and transaction cost } \\
\text { Area not under community forestry regime } \\
\text { National forest could be more exploited due to } \\
\text { lack of management plan } \\
\text { Limited support from value chain supporters }\end{array}$ \\
\hline
\end{tabular}

\section{Discussion}

Government of Nepal has listed C. glaucescens as important species among 30 different medicinal and aromatic plants in Nepal (DoF 2012). The collection and sale of non-timber forest products is the major source of income in some regions of Nepal (Marasini et al. 2006; Paudel et al. 2012). Present study revealed that hundred percent of the farmers in the study site are engaged in collection and sale of $C$. glaucescens for their livelihood. The share of income from C. glaucescens was found more than fifty percent $(53 \%)$ of the average household income. Despite huge potentiality of contribution of non-timber forest products to rural economy, over exploitation and unscientific harvesting have been identified as the major causes of the depletion of NTFPs in Nepal (Edwards 1996). Alam and Belt (2009) had also concluded that the depletion of medicinal herbs at a rapid pace was due to over collection from their natural habitats. Larsen et al. (2000) found the cause of over-exploitation of resource due to absence of any qualitative studies on ecological condition of the NTFPs in Nepal. Pandit (2008) had identified the open access status of national forest for the collection of NTFPs and suggested to handover the national forest as community forest for sustainable harvesting of the products. Present study showed that $C$. glaucescens has also been over exploited from the district. The forest in the study area has neither been handed over as community forest nor has any management plan been developed by the division forest office. Local people are using the forest as 
open access resources that have faced over harvesting and poor management operation. As a result, regeneration of $C$. glaucescens is poor in the study area.

NTFP value chain development usually involves six to seven marketing channels involving primary collectors and producers, local contractors, regional wholesale markets, large wholesale markets and specialized end products manufacturers (Hishe et al. 2016).In the trade of C. glaucescens, six different layers of individuals/groups from collector to exporters were involved but there is poor functional linkages. Alam and Belt (2009) and Shahidullah and Haque (2010) have found that downstream buyers, especially processors and consumers, pay most of their money for intermediaries' value additive opportunistic pricing due to inherent weaknesses in the chain. They have argued that in order to sustain the medicinal plant production, a fair distribution of the gross margin to the primary producers is necessary. This study shows that value of each $\mathrm{kg}$ of $C$. glaucescens upgrades nearly five times from NPR 150 to NPR 732.48 with medium profit $(25.9 \%$ of total value addition) to producers.

Lack of financial access and poor drying infrastructure were identified as major constraints for the value chain development of the non-timber forest products in Nepal (Maraseni et al. 2006; Paudel et al. 2012). This study also identified poor access to finance and modern drying technology as major constraints in the value chain development of $C$. glaucescens. Due to the poor financial access, the producers were compelled to harvest un-matured fruit and sold at minimum price to cover the festival expenditure.

Previous studies (Rai and Chapagain 2014; Shah et al. 2018) have shown that middlemen get maximum profit margin. Piya et al. (2011) identified the producers as the weakest actors in the NTFP market chain and thus they have least bargaining position. However, this study found that producers had second largest profit margins $(25.9 \%)$ after the wholesalers $(36.5 \%)$; but the price fluctuation was found a major threat for the economic potentiality of the products. Simlar findings was made for other medicinal and aromatic plants trade in the region (Astutik et al. 2019). In order to increase the share of profit of producers/collectors, Maraseni et al. (2006) and Pandit (2008) have recommended shortening the marketing channel of middlemen. Present study also identified the village traders as unnecessary actors in value chain and could be reduced by linking producers with processors.

\section{Conclusions}

C. glaucescens was found as a prominent NTFP species to contribute to local as well as sub-national economy of Rapti region of Nepal. The contribution of NPR 1.7 million to twenty nine rural households is quite high in the context of Nepal; however, due to poor role of value chain supporters and poor linkage of the value chain actors, the sustainability of the value chain is questionable. The major actors in value chain of $C$. glaucescens are producers, traders, processors, collectors and exporters. Value chain analysis shows that if proper mechanism to link the producers 
directly with regional traders could be strengthened, the profit margin of producers could be increased by NRs $8 \mathrm{~kg}^{-1}$ which can be achieved by reducing the value chain layers such as village traders. As the forest is not handed over as community forest and there is lack of forest management plan in the division forest office, local people usually collect berries intensively from national forest without any sustainable harvesting practices. The promotion of $C$. glaucescens and up gradation of value chain could not only enhance the local economy but also contribute to sub-national economy in the entire region.

\section{Literature Cited}

Adhikari, S. 2018. Essential Oils of Nepal (In: J.J. Bhatta, S. Upadhayay,T.D. Bhatta, S.Panthi \& R. Aryal Eds.). Department of Plant Resource, Thapathali, Kathmandu, Nepal. 213 p.

Alam, G. and J. Belt. 2009. Developing a medicinal plant value chain: Lessons from an initiative to cultivate Kutki (Picrorhiza kurrooa) in Northern India. KIT Working Papers Series C5.Amsterdam, 2009. 111 p.

Astutik, S., J. Pretzsch, and N. K. Jude. 2019. Asian Medicinal Plants' Production and Utilization Potentials: A Review. Sust. 11 (2): 54-83.

DCC. 2018. State Restructure Report for Dang District. District Coordination Committee, Dang Nepal. 65 p.

DDC. 2013. District Profile, 2071. District Development Committee, Dang, Nepal. $23 \mathrm{p}$.

DFO. 2017. Annual Report, 2074. District Forest Office, Dang. 43 p.

DFO. 2018. Resource Inventory of Selected Non Timber Forest Products in Dang district. Division Forest Office, Dang, Nepal. 32 p.

DoF. 2012. Non-timber Forest Products Inventory Guideline. Department of Forest, Ministry of Forest and Soil Conservation, Nepal (In Nepali). 23 p.

DPR. 2012. Plants of Nepal: Fact Sheet. Government of Nepal, Ministry of Forest and Soil Conservation, Department of Plant Resource, Thapathali, Kathmandu, Nepal. 56 p.

Edwards, D.M. 1996. The Trade in Non-Timber Forest Products from Nepal. Mountain Research and Development 16(4): 1-8.

GIZ. 2011. Medicinal and Aromatic Plants, Poverty Impact Assessment (PIA) of proposed Trade Support Measures in Nepal's Medicinal and Aromatic Plants of Nepal. Deutsche Gessellschaft fur InternationaleZusarmmenarbeit (GIZ) $\mathrm{GmbH}$, Kathmandu, Nepal. 25 p. 
GoN. 1995. Forest Regulation, 1995. Ministry of Forest \& Soil Conservation, Government of Nepal, Kathmandu. 87 p.

Gurung, K. 2010. Essential oil sector study in Nepal: A detailed study of Anthopogan, Juniper and Wintergreen essential oil. Deutsche Gessellschaft fur InternationaleZusarmmenarbeit (GIZ) GmbH, Kathmandu, Nepal. 98 p.

Hishe M., Z. Asfaw and M. Giday. 2016. Review on value chain analysis of medicinal plants and the associated challenges. Journal of Medicinal Plants Studies, 4(3): $45-55$.

Jackson, J.K. 1994. Manual of afforestation in Nepal. Vol. 2. Forest Research Survey Centre, Kathmandu, Nepal. 334 p.

Larsen, H. O., C. S. Olsen and T.E. Boon. 2000. The non-timber forest policy process in Nepal: actors, objectives and power. Forest Policy and Economics, 1(2): 267281.

Maraseni, T.N., G.P. Shivakoti, G. Cockfieldand A. Apan. 2006. Nepalese non-timber forest products: an analysis of the equitability of profit distribution across a supply chain to India. Small-scale Forest Economics, Management and Policy, 5(2): 191- 206.

Mohan, S. 2016. Institutional Change in Value Chains: Evidence from Tea in Nepal. World Development, 78(2): 52-65.

Pandit, B. H. 2008. Economics of non-timber forest production promotion and marketing: a case study from Malekhukhola Watershed of Dhading district, Nepal. The Initiation, 2: 145-156.

Paudel, A., B. P. Subedi, S. Gyawali, G. K. Thapa and M. B. Sharma. 2012. Value chain analysis of non-timber forest products in Baglung district, Nepal. Banko Janakari, 19(2):33-41.

Piya, L., K.L. Maharjan, N.P. Joshi and D.R. Dangol. 2011. Collection and Marketing of Non-timber forest products by Chepang Community in Nepal. The Journal of Agriculture and Environment, 12(1):10-21.

Rani, A., C. Pandey, G. Tiwari and K. Patni. 2017. A Review of Aroma Profile of Cinnamomum species in Northern and North East India. World Journal of Pharmaceutical Research, 6(11): 200-221.

Rai, J. K. and S. P. Chapagain. 2014. Value Chain Analysis of Forest Products in Koshi Hill Districts of Nepal: Challenges and Opportunities for Economic Growth. Forest Action Nepal and RRN, Kathmandu 27 p. 
Reema, J., B. Krishnamoorthy, B. Sasikumar, K. Saji and P. Mathew. 2002. Cinamomum Cecidodaphne Messin,A new addition to Cinnamomum Germplasm.Indian Journal of Arecanut, Spices \& Medicinal Plants.Indian Institute of Spices Research 4(1):59-61.

Shah G. M., A. K. Nepal, G. Rasul, and F. Ahmad. 2018. Value chain development of bay leaf in Nepal: an impact assessment, Journal of Development Effectiveness, 10(2):179-196.

Shahidulla, A. K. M. and E. C. Haque. 2010. Linking medicinal plant production with livelihood enhancement in Bangladesh: Implications of a vertically integrated value chain. The Journal of Trans disciplinary Studies 9(2):30-46.

TEPC. 2018. Trade Promotion Database. Trade and Export Promotion Centre, Kathmandu, Nepal 34 p.

VDC. 2010. Village Profile. Bijauri Village Development Committee, Bijauri, Dang. 